\title{
Ultrasound-guided lateral versus posterior Quadratus Lumborum Block for postoperative pain after laparoscopic cholecystectomy: a randomized controlled trial
}

\author{
Korgün Ökmen ${ }^{1}$, Burcu Metin Ökmen², Erkan Sayan ${ }^{1}$ \\ ${ }^{1}$ Clinic of Anesthesiology and Reanimation, University of Health Sciences, Bursa Yuksek Ihtisas Training and Research Hospital, Bursa, Turkey \\ ${ }^{2}$ Clinic of Physical Medicine and Rehabilitation, University of Health Sciences, Bursa Yuksek Ihtisas Training and Research Hospital, Bursa, Turkey
}

\begin{abstract}
Objective: The aim of the present study was to investigate the effect of ultrasound-guided bilateral posterior quadratus lumborum block (QLB) and lateral QLB on postoperative pain scores after laparoscopic cholecystectomy.

Material and Methods: In this prospective, randomized, single-blind study; 60 patients with elective laparoscopic cholecystectomy operations were randomized into two groups as group P ( $n=30)$ : Posterior Quadratus Lumborum Block + IV patient-controlled analgesia (PCA) tramadol and group L $(n=30)$ : Lateral Quadratus Lumborum Block + IV PCA tramadol. Primary outcome measures included the amount of total consumption (24 hours) of tramadol. Secondary outcome measures; Visual Analog Scala (VAS) scores at rest and on movement (postoperative $30^{\text {th }}$ minute, $2^{\text {nd }}, 6^{\text {th }}, 12^{\text {th }}$, and $24^{\text {th }}$ hours) were recorded. Adverse effects (nausea and vomiting), additional analgesic requirement, and intraoperative opioid requirement were recorded. Results: Postoperative total consumption amounts of tramadol and VAS scores (rest and on movement) were compared, and there was no statistically significant difference between the two groups ( $p>0.05$ ). There was no statistically significant difference in adverse effects (nausea and vomiting), additional analgesic requirement, and intraoperative opioid requirement between the two groups $(p>0.05)$.
\end{abstract}

Conclusion: Similar postoperative tramadol consumption values and VAS scores were determined in both lateral QLB and posterior QLB block applications in the results of our study.

Keywords: Cholecystectomy, quadratus lumborum block, postoperative pain, laparoscopy, ultrasound

Cite this article as: Ökmen K, Metin Ökmen B, Sayan E. Ultrasound-guided lateral versus posterior Quadratus Lumborum Block for postoperative pain after laparoscopic cholecystectomy: a randomized controlled trial. Turk J Surg 2019; 35 (1): 23-29

Corresponding Author Korgün Ökmen

E-mail: korgunokmen@gmail.com

Received: 20.03 .2018

Accepted: 24.04 .2018

Available Online Date: 01.03.2019

O Copyright 2019 by Turkish Surgical Society Available online at www.turkjsurg.com

DOI: 10.5578/turkjsurg.4161

\section{INTRODUCTION}

Laparoscopic cholecystectomy causes less pain and shortens the healing period when compared to open surgery. Today, since it provides a shorter length of hospital stay, it can be admitted in the status of the same-day patient $(1,2)$. Pain type after laparoscopy is different from laparotomy, although detected mostly as parietal pain (with abdominal wall origin), patients also complain of visceral pain resulting from pneumoperitoneum (3). Many analgesic procedures such as nonsteroidal anti-inflammatory drugs (NSAIDs), opioid and regional anesthesia procedures are used as part of multimodal analgesia for postoperative pain $(3,4)$. Among the regional anesthesia techniques of abdominal surgery, thoracic epidural analgesia, paravertebral block and transversus abdominis plane (TAP) block are used (4). TAP block, which is one of the truncal blocks, has been used in many studies in the literature for pain palliation after abdominal surgery (4-6). Another trunk block that has been used in recent years is the Quadratus Lumborum Block (QLB). It is described as the administration of local anesthetic between the quadratus muscle and the medial layer of the thoracolumbar fascia in an ultrasound-guided manner. It has been reported that a wider sensorial block area can be obtained from the single injection of QLB when compared to those obtained from the TAP block $(7,8)$. Different studies have suggested that analgesia could be achieved up to the level of T5-L1 after QLB, and that it has an effect on both somatic pain and visceral pain (8-10). The block, which can be applied in four different ways to the quadratus lumborum muscle, namely, laterally, posteriorly, anteriorly and intramuscularly, has been administered laterally 
for the first time by Blanco et al. using local anesthetic injection (7). The efficacy of QLB administered with different indications in numerous case reports in the literature has been attempted to be determined with a limited number of randomized controlled studies $(11,12)$.

The aim of the present study was to investigate the effect of ultrasound-guided bilateral posteriorly (posterior QLB) and laterally administered (lateral QLB) QLB on the postoperative pain scores after laparoscopic cholecystectomy.

\section{MATERIAL and METHODS}

\section{Patients}

Sixty-five patients who were planned to undergo laparoscopic cholecystectomy were evaluated within the scope of this prospective, randomized, single-blind study after obtaining the approval of the local ethics committee (Ethical number 201713/56). Patients who were aged between 20 and 60 years, who were included in the American Society of Anesthesiologists (ASA) I-III classes and who would undergo elective laparoscopic cholecystectomy were included. Patients with local anesthetic allergy, systemic infection, uncontrolled diabetes and hypertension were excluded from the study.

\section{Randomization}

Sixty suitable patients who accepted to participate in the study and who gave written consent were randomized into two groups with random numbers table including group $P(n=30)$ : Ultrasound-guided bilateral Posterior QLB with $0.3 \mathrm{~mL} / \mathrm{kg} 0.25 \%$ bupivacaine (Marcaine \%0.5 AstraZeneca, İstanbul, Turkey) + IV patient-controlled analgesia (PCA) tramadol $\left(\right.$ Tramose ${ }^{\circledR}$, Haver, İstanbul, Turkey) and group $L(n=30)$ : Ultrasound-guided bilateral Lateral QLB with $0.3 \mathrm{~mL} / \mathrm{kg}$ 0.25\% bupivacaine + IV patientcontrolled analgesia (PCA) tramadol (Figure 1).

\section{Interventions}

Quadratus Lumborum Blocks were administered before operation and general anesthesia. After abdominal wall muscles were identified as three layers with the linear probe $(10-18 \mathrm{MHz}$ MyLab30; Esaote, Florence, Italy), the probe was directed posteriorly and the fascia transversalis (TF), thoracolumbar fascia and Quadratus lumborum (QL) muscles were visualized (10). After

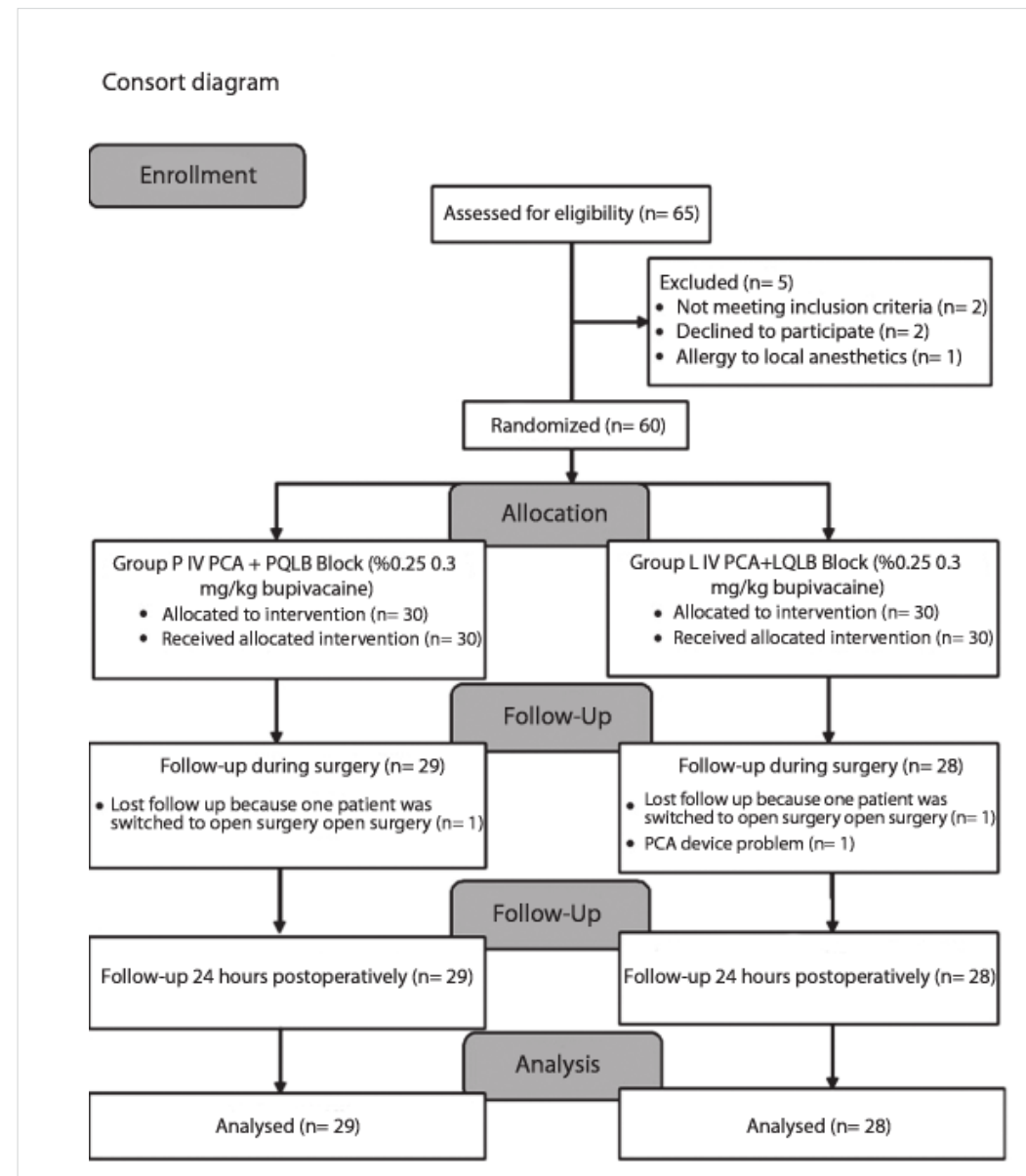

Figure 1. Flow chart of the study. 
the area to be intervened was disinfected, the local anesthetic was administered using a 21-gauge, 100-mm needle (Quincke SonoPlex Pajunk, Geisingen, Germany) with the in-plane technique between the middle layer of the thoracolumbar fascia and QL muscle at the posterior edge of the quadratus lumborum muscle for posterior QLB, and between the aponeurosis at the lateral edge of the QL muscle and TF after the place was confirmed with the hydrodissection for lateral QLB (the target point was the junction between fascia and QL muscle) $(8,10)$ (Figures 2,3). Bupivacaine was used at a concentration of $0.25 \%$ and at a dose of $0.3 \mathrm{mg} / \mathrm{kg}$ in both groups. It was administered to both groups bilaterally by the same regional anesthetist using a 10-18 MHz linear probe (MyLab30; Esaote, Florence, Italy). Propofol (Propofol 2\% Fresenius ${ }^{\circledR}$, Fresenius Kabi, Bad Homborg, Germany) $1-2 \mathrm{mg} / \mathrm{kg}$ and rocuronium (Curon ${ }^{\circledR}$, Mustafa Nevzat, İstanbul, Turkey) 0.8-1.0 mg/kg were used for anesthesia induction. The maintenance of anesthesia was achieved with sevoflurane (Sevorane ${ }^{\circledR}$ Likit \%100, AbbVie, Queenborough, England)
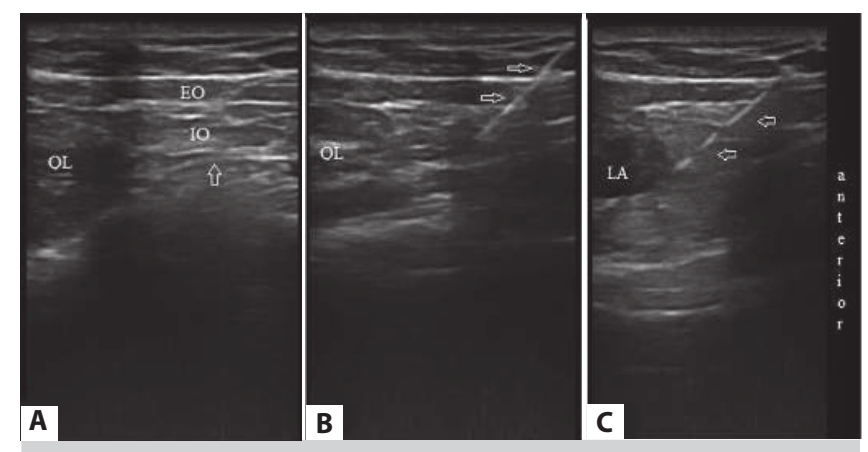

Figure 2. Ultrasound imaging lateral Quadratus Lumborum Block.

(A): QL: Quadratus Lumborum muscle, EO: External oblique muscle, IO: Internal oblique muscle, arrow shows fascia transversalis.

(B): QL: Quadratus Lumborum muscle, arrows show ultrasonic visible needle.

(C): LA: Local anesthesic, arrows show ultrasonic visible needle.
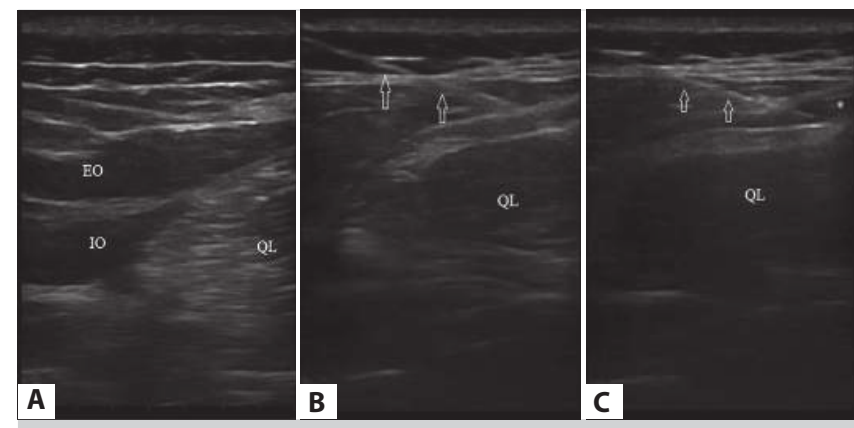

Figure 3. Ultrasound imaging posterior Quadratus Lumborum Block. (A): QL: Quadratus lumborum muscle, EO: External oblique muscle, IO: Internal oblique muscle.

(B): QL: Quadratus lumborum muscle, arrows show ultrasonic visible needle.

(C): QL: Quadratus lumborum muscle.

* Local anesthesic, arrows show ultrasonic visible needle.
$3-5 \%$ and a flow of $2.5-3 \mathrm{~L} / \mathrm{min}$ including the mixture of air and O2. Analgesia was provided with $1 \mu \mathrm{g} / \mathrm{kg}$ fentanyl (Talinat ${ }^{\circledR}$, Vem, İstanbul, Turkey) when needed. Twenty minutes to the end of the operation, tenoxicam (Tilcotil, Deva Illaç, İstanbul, Turkey) 20 mg IV was administered for postoperative analgesia. IV PCA (CADD-Legacy ${ }^{\circledR}$ PCA, Smiths Medical, St. Paul, USA) device was connected to the postoperative patient and a bolus dose of tramadol was administered. The saline solution prepared as 5 mg tramadol per $\mathrm{mL}$ was mounted on the PCA instrument for the IV PCA protocol. The PCA device was set to the lock duration of $30 \mathrm{~min}$, demand dose of $25 \mathrm{mg}$ and the daily maximum dose of $400 \mathrm{mg}$. The bolus dose was administrated in the recovery room to those with a postoperative VAS score over 4 points.

Surgical procedure: The surgical technique applied to all patients was performed in an identical manner by the same team of surgeons. Laparoscopy was performed by a 4 trocar technique (the first trocar was introduced inferiorly to the umbilicus, the second one was introduced inferiorly to the xiphoid process just on the left side of the upper $1 / 3$ portion of the umbilical-xiphoid distance, the third one was introduced at the point of intersection of the umbilicus with the right anterior axillary line below the right costal arch, and the fourth one was introduced on the right midclavicular line). During the procedure, the intraabdominal pressure was maintained at a limit of maximum $14 \mathrm{mmHg}$.

\section{Outcome Measures}

Primary outcome measures; The amount of the total consumption of tramadol was examined. Secondary outcome measures; VAS scores at rest and on movement (Postoperative $30^{\text {th }}$ minute, $2^{\text {nd }}, 6^{\text {th }}, 12^{\text {th }}$, and $24^{\text {th }}$ hours) were recorded. Adverse effects (nausea and vomiting), additional analgesic requirement, intraoperative opioid requirement and duration of surgery were recorded.

\section{Statistical Analysis}

The analysis of the data was performed using IBM SPSS 22.0 (Chicago, IL, USA) statistical package program. Chi-square (c2) test was used for the comparisons of descriptive statistical methods (frequency, percentage, mean, standard deviation, median, minmax) as well as those of the qualitative data while assessing the study data. Conformity of the data with normal distribution was evaluated by Kolmogorov-Smirnow test (the data were found to be non-normally distributed.). For comparisons among groups, Mann-Whitney U test was used. It was considered that probability $(P)$ values lesser than $a=0.05$ were significant and there was a difference among groups while the values higher than that value were insignificant and there was no difference among groups.

Power analysis: In the result of the pilot study conducted in our clinic, a total of 58 patients with the necessary sample size of 29 was calculated for the study power of $90 \%(a=0.05)$ when a $40 \%$ reduction was expected in 24-hour tramadol consumption values $(82.5 \pm 41.17 \mathrm{mg}) . \mathrm{G}$ * Power3 analysis program (Heinrich-Heine- 
Universität Düsseldorf, Düsseldorf, Germany) was used for calculation. In order to increase the power of the study and considering the potential losses, 30 patients were planned to be included in each group.

\section{RESULTS}

The study was terminated with a total of 57 patients since it was switched to open surgery in one patient in the posterior QLB group ( $n=29$ ), and it was switched to open surgery in one patient and due to a PCA device problem in one patient in the lateral QLB group $(n=28)$. Patient demographics and fentanyl levels administered during the operation were shown in Table 1. There was no statistically significant difference in terms of these values among the groups ( $p>0.05)$. When postoperative total consumption amounts of tramadol were compared, consumption was determined to be 51.78 (0-175) mg in Group P and 54.46 (0-175) mg in group $\mathrm{L}$. There was no statistically significant difference between the two groups ( $p>0.05$ ) (Figure 4). Examining the VAS scores at rest and on movement, no statistically significant difference was detected among all time parameters in inter-group analyses ( $p>$ 0.05) (Tables 2,3). There was no statistically significant difference in the frequency of side effects, consumption of paracetamol as rescue analgesia and duration of the operation between the two groups ( $p>0.05)$ (Table 4).

Table 1. Comparison of the demographic characteristics of the patients

\begin{tabular}{|c|c|c|c|}
\hline & $\begin{array}{c}\text { Group P } \\
(n=29)\end{array}$ & $\begin{array}{l}\text { Group L } \\
(n=28)\end{array}$ & $\mathbf{p}$ \\
\hline Age (year) & $38 \pm 8.51$ & $39.5 \pm 7.4$ & 0.834 \\
\hline Height (cm) & $164.26 \pm 7.63$ & $162.5 \pm 7.4$ & 0.367 \\
\hline Weight (kg) & $68.7 \pm 8.1$ & $69 \pm 9.13$ & 0.830 \\
\hline Gender & $13(44.8 \%) / 16(55.2 \%)$ & $10(35.7 \%) / 18(64.3 \%)$ & 0.487 \\
\hline Amount of opioid given during operation $(\mu \mathrm{g})$ & $86.78(60-150)$ & $87(80-160)$ & 0.980 \\
\hline
\end{tabular}

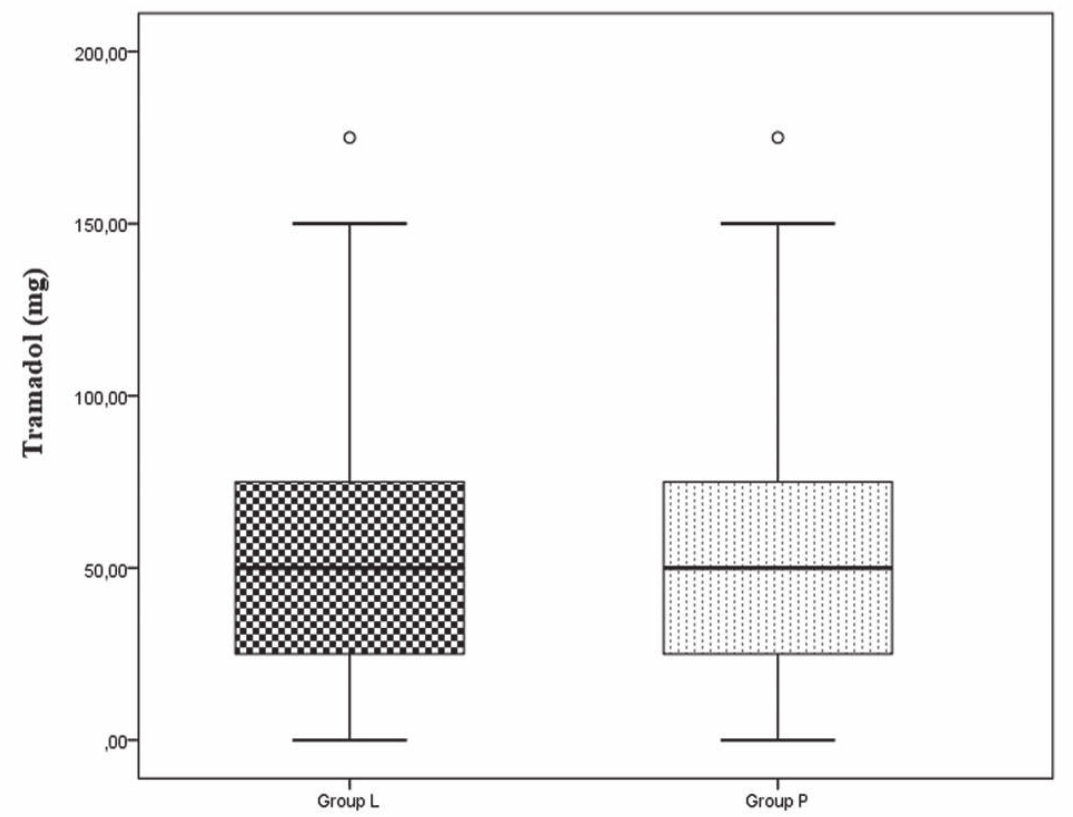

Figure 4. Tramadol consumption in the first 24 hour following surgery. Median (min; max) values for abnormal distribution. The Mann-Whitney $U$ test for the inter-group comparisons. Group P: Ultrasound-guided bilateral Posterior quadratus lumborum block + IV patient-controlled analgesia tramadol and Group L: Ultrasound-guided bilateral Lateral quadratus lumborum block + IV patient-controlled analgesia tramadol. 


\begin{tabular}{|c|c|c|c|}
\hline VAS (at rest) & $\begin{array}{l}\text { Group P } \\
(n=29)\end{array}$ & $\begin{array}{c}\text { Group L } \\
(n=28)\end{array}$ & p \\
\hline $30^{\text {th }}$ minute & $0.75(0-3)$ & $1.07(0-3)$ & 0.245 \\
\hline $2^{\text {nd }}$ hour & $0.89(0-3)$ & $1.1(0-3)$ & 0.340 \\
\hline $6^{\text {th }}$ hour & $1.03(0-3)$ & $1.25(0-3)$ & 0.343 \\
\hline $12^{\text {th }}$ hour & $1.1(0-3)$ & $1.14(0-3)$ & 0.873 \\
\hline $24^{\text {th }}$ hour & $0.86(0-4)$ & $1.10(0-3)$ & 0.246 \\
\hline
\end{tabular}

Table 3. Comparison of VAS scores at movement between groups

\begin{tabular}{|c|c|c|c|}
\hline VAS (at movement) & $\begin{array}{l}\text { Group P } \\
(n=29)\end{array}$ & $\begin{array}{l}\text { Group L } \\
(n=28)\end{array}$ & $p$ \\
\hline $2^{\text {nd }}$ hour & $1.10(0-3)$ & $1.28(0-3)$ & 0.627 \\
\hline $6^{\text {th }}$ hour & $1.17(0-4)$ & $1.39(0-4)$ & 0.578 \\
\hline $12^{\text {th }}$ hour & $1.2(0-4)$ & $1.64(0-4)$ & 0.140 \\
\hline $24^{\text {th }}$ hour & $1.68(0-4)$ & $1.78(0-4)$ & 0.766 \\
\hline
\end{tabular}

Table 4. Side effects, additional analgesic requirement, duration of surgery

\begin{tabular}{|l|c|c|c|}
\hline & $\begin{array}{c}\text { Group P } \\
\text { (n= 29) }\end{array}$ & $\begin{array}{c}\text { Group L } \\
\text { (n= 28) }\end{array}$ & $1(3.4 \%)$ \\
\hline Side effects nausea and vomiting & - & $1(3.6 \%)$ & 0.309 \\
\hline Additional analgesic requirement & - & 6.309 \\
\hline Duration of surgery (minute) & $63.5 \pm 14$ & 15.6 \\
\hline $\begin{array}{l}\text { Mean } \pm \text { SD for normal distribution. Group P: Ultrasound-guided bilateral Posterior quadratus lumborum block + IV patient-controlled analgesia tramadol and } \\
\text { Group L: Ultrasound-guided bilateral Lateral quadratus lumborum block + IV patient-controlled analgesia tramadol. }\end{array}$ \\
\hline
\end{tabular}

\section{DISCUSSION}

Efficacy was investigated in this study by comparing the posterior QLB group with the lateral QLB group after laparoscopic cholecystectomy. In the study results, no statistically significant difference was found between the VAS scores at rest and on movement and PCA tramadol consumption values at all postoperative measurement times.

Trunk blocks are frequently used for laparoscopic cholecystectomy and abdominal surgeries. TAP block is a popular truncal block with shown efficacy in many different studies whereas QLB is a new block which has begun to be used recently. Blanco et al. have used the block application defined as "no pops" for pain after abdominoplasty surgery. Local anesthesia administered by them to the quadratus muscle laterally has been stated to provide effective analgesia (7). Afterwards, the injection performed in the quadratus muscle posteriorly has been reported to be more effective than the injection performed laterally in two different studies, and they have suggested that it causes lesser morphine consumption and need compared to the patients to whom TAP block has been administered $(8,10)$.

Apart from the case reports in the literature, they have attempted to investigate the efficacy of QL block in three different studies $(9,13,14)$. Murocchi et al. have administered QLB and TAP blocks to 22 patients in two studies aiming to determine the efficacy of QLB after laparoscopic surgery in patients with gynecologic disease. In the results examined retrospectively, a sensory block has been found throughout the dermatomes of T7-L1 in the QLB-treated group, and it has been reported to provide analgesia for 24 hours. The spread of local anesthesia administered to the paravertebral area due to the anatomical connection of the fascia transversalis with endothoracic fascia has been suggested as the potential activity mechanism in the study in which posterior QLB has been applied (9). In another study by Ishio et al. in which they have administered posterior QLB and compared it with the placebo group in the RCT, they 
have detected that QLB block has lower VAS (on movement and at rest) values than the placebo (13). In this study in which $20 \mathrm{~mL}$ of ropivacaine has been used, nausea, vomiting and the time to the first analgesic requirement have been found to be lower in the block administered group. The results of these two studies in which laparoscopic surgery was performed reached to similar results with our study. Although QLB has been found to be effective after inguinal hernia operation in the RCT results performed in pediatric patients, the discussions on the activity mechanism of the block have been addressed. One of the main activity mechanisms is blocking the sympathetic formations in the facial plane with local anesthetic, which has been suggested by Blanco et al (14). Another opinion is the paravertebral spread through the endothoracic fascia which is the continuation of the transversal fascia due to its anatomic structures (8).

However, in addition to the studies detecting paravertebral spread in cadaver studies, there are also studies presenting different findings (15-18). Dam et al. have commented rather on the anterior QLB in cadaver studies and reported that paravertebral spread is detected at a significant level (15). Another study has reported that the local anesthetic substance administered to the quadratus muscle laterally and posteriorly has similar spreads. They have stated that the involvement of lumbar plexus by posterior QLB is possible (16).

Whereas Kumar et al. have indicated that paravertebral spread is not possible and presented the fact that the local anesthetics administered though paravertebral route did not spread to the lumbar region in previous studies as the pivotal point (17). Their theory was that the effect of OLB block on visceral pain was through the sympathetic chain or celiac ganglion blockade (17). On the other hand, the inability of cadaver studies to show the full extent of local anesthetic spread in the living body seems to be a disadvantage (18). For the activity mechanism of QLB, which is a new regional block, to meet at a common point, more studies seem to be needed.

Whereas, the results of our study were similar to those studies conducted on QLB. Postoperative VAS and opioid consumption amounts of the injections administered to the quadratus muscle laterally and posteriorly were similar in laparoscopic cholecystectomy operations. The discriminating point between these two types of blocks appears to be the anatomical location of the injection site. Previous studies have noted that interventions directed to the posterior part of the quadratus lumborum muscle may be safer due to the fact that the intervention area is closer to the intra-abdominal organs (10).

\section{Study Limitation}

The limitations of the study include not having monitored the block level although block was administered preoperatively and the fact that the patients were not followed up for longer than 24 hours. Another limitation is that we could not calculate tramadol consumption at specific time intervals and we didn't measure the amount of gas used for pneumoperitoneum.

\section{CONCLUSION}

Similar postoperative tramadol consumption values and VAS scores were determined in both lateral QLB and posterior QLB applications in the results of our study. Therefore, we suggest that both injections are effective in analgesia after laparoscopic cholecystectomy. The ease in ultrasound imaging and anatomical neighborhoods may be the reason for the preference of QLB type to be administered.

Ethics Committee Approval: All procedures performed in studies involving human participants were in accordance with the ethical standards of the institutional and/or national research committee and with the $1964 \mathrm{Hel}-$ sinki declaration and its later amendments or comparable ethical standards.

Informed Consent: Informed consent was obtained from all individual participants included in the study.

Peer-review: Externally peer-reviewed.

Author Contributions: Consept - K.Ö., B.M.Ö., E.S.; Design - K.Ö., B.M.Ö., E.S.; Supervision - K.Ö., B.M.Ö., E.S.; Resource - K.Ö., B.M.Ö.; Materials - K.Ö., E.S.; Data Collection and/or Processing - K.Ö., B.M.Ö., E.S.; Analysis and Interpretation - K.Ö., B.M.Ö., E.S.; Literature Search - K.Ö., B.M.Ö.; Writing Manuscript - K.Ö., B.M.Ö., E.S.; Critical Reviews - K.Ö., B.M.Ö., E.S.

Conflict of Interest: The authors have no conflicts of interest to declare.

Financial Disclosure: The authors declared that this study has received no financial support.

\section{REFERENCES}

1. Bandey S, Singh V. Comparison between IV paracetamol and tramadol for postoperative analgesia in patients undergoing laparoscopic cholecystectomy. J Clin Diagn Res 2016; 10: UC05-9. [CrossRef]

2. Michaloliakou C, Chung F, Sharma S. Preoperative multimodal analgesia facilitates recovery after ambulatory laparoscopic cholecystectomy. Anesth Analg 1996; 82: 44-51. [CrossRef]

3. Ure BM, Troidl H, Spangberger W, Dietrich A, Lefering R, Neugebauer E. Pain after laparoscopic cholecystectomy. Surg Endosc 1994; 8: 90-6. [CrossRef]

4. Niraj G, Kelkar A, Jeyapalan I, Graff-Baker P, Williams O, Darbar A, et al. Comparison of analgesic efficacy of subcostal transversus abdominis plane blocks with epidural analgesia following upper abdominal surgery. Anaesthesia 2011;66:465-71. [CrossRef]

5. Carney J, Finnerty O, RaufJ, Bergin D, Laffey JG, Mc Donnell JG. Studies on the spread of local anaesthetic solution in transversus abdominis plane blocks. Anaesthesia 2011; 66: 1023-30. [CrossRef]

6. Bhatia N, Arora S, Jyotsna W, Kaur G. Comparison of posterior and subcostal approaches to ultrasound-guided transverse abdominis plane block for postoperative analgesia in laparoscopic cholecystectomy. J Clin Anesth 2014; 6: 294-9. [CrossRef]

7. Blanco R. Tap block under ultrasound guidance: the description of a "no pops" technique: 271. Reg Anesth Pain Med 2007: 32: 130. [CrossRef]

8. Blanco R, Ansari T, Riad W, Shetty N. Quadratus lumborum block versus transversus abdominis plane block for postoperative pain after cesarean delivery. Reg Anesth Pain Med 2016; 6: 757-62. [CrossRef] 
9. Murouchi T, Iwasaki S, Yamakage M. Quadratus lumborum block: analgesic effects and chronological Ropivacaine concentrations after laparoscopic surgery. Reg Anesth Pain Med 2016; 41: 146-50.[CrossRef]

10. Blanco R, Ansari T, Girgis E. Quadratus lumborum block for postoperative pain after caesarean section: a randomised controlled trial. Eur J Anaesthesiol 2015; 32: 812-8. [CrossRef]

11. Børglum J, Gögenür I, Bendtsen TF. Abdominal wall blocks in adults. Curr Opin Anaesthesiol 2016; 29: 638-43. [CrossRef]

12. Elsharkawy H. Quadratus lumborum blocks. Adv Anesth 2017; 35: 145-57. [CrossRef]

13. Ishio J, Komasawa N, Kido H, Minami T. Evaluation of ultrasoundguided posterior quadratus lumborum block for postoperative analgesia after laparoscopic gynecologic surgery. J Clin Anesth 2017; 41: 1-4. [CrossRef]

14. Öksüz G, Bilal B, Gürkan Y, Urfalioglu A, Arslan M, Gisi G, et al. Quadratus lumborum block versus transversus abdominis plane block in children undergoing low abdominal surgery: a randomized controlled trial. Reg Anesth Pain Med 2017; 42: 674-9. [CrossRef]
15. Dam M, Morigg/ B, Hansen CK, Hoermann R, Bendtsen TF, Børglum J. The pathway of injectate spread with the transmuscular quadratus lumborum block: a cadaver study. Anesth Analg 2017; 125: 303-12. [CrossRef]

16. Carline L, McLeod GA, Lamb C. A cadaver study comparing spread of dye and nerve involvement after three different quadratus lumborum blocks. Br J Anaesth 2016; 117: 387-94. [CrossRef]

17. Kumar A, SadeghI N, Wahal C, Gadsden J, Grant SA. Quadratus lumborum spares paravertebral space in fresh cadaver injection. Anesth Analg 2017; 21: 708-9. [CrossRef]

18. Adhikary SD, ElBoghdadly K, Nasralah Z, Sarwani N, Nixon A M, Chin $K J$. A radiologic and anatomic assessment of injectate spread following transmuscular quadratus lumborum block in cadavers. Anaesthesia 2017; 72: 73-9. [CrossRef]

\title{
ORIJINAL ÇALIŞMA-ÖZET
}

Turk J Surg 2019; 35 (1): 23-29

\section{Laparoskopik kolesistektomi sonrası postoperatif ağrı için ultrason kılavuzluğunda lateral ve posterior Quadratus Lumborum Bloğu: Randomize kontrollü çalışma}

\author{
Korgün Ökmen ${ }^{1}$, Burcu Metin Ökmen², Erkan Sayan ${ }^{1}$ \\ ${ }^{1}$ Sağlık Bilimleri Üniversitesi, Bursa Yüksek Ihtisas Eğitim ve Araştırma Hastanesi, Anestezi ve Reanimasyon Kliniği, Bursa, Türkiye \\ ${ }^{2}$ Sağ Ilk Bilimleri Üniversitesi, Bursa Yüksek Ihtisas Eğitim ve Araştırma Hastanesi, Fizik Tedavi ve Rehabilitasyon Kliniği, Bursa, Türkiye
}

\section{ÖZET}

Giriş ve Amaç: Bu çalışmanın amacı, ultrasonografi eşliğinde yapılan bilateral posterior Quadratus Lumborum Blok (QLB) ve lateral QLB'nin laparoskopik kolesistektomi sonrası postoperatif ağrı skorlarına etkisini araştırmaktır.

Gereç ve Yöntem: Bu prospektif, randomize, tek kör çalışmada; elektif laparoskopik kolesistektomi operasyonu geçirecek 60 hasta grup P ( $n=30)$ : Posterior Quadratus Lumborum Blok + IV hasta kontrollü analjezi (PCA) tramadol ve grup L $(n=30)$ : Lateral Quadratus Lumborum Blok + IV PCA tramadol olacak şekilde randomize edildi. Primer sonuç ölçütleri toplam tramadol tüketim ( 24 saat) miktarını içermektedir. İkincil sonuç ölçütleri ise dinlenme ve hareket halinde "Visüal Analog Scala (VAS)" skorları (postoperatif 30. dakika, 2, 6, 12 ve 24. saat) kaydedildi. Yan etkiler (bulantı ve kusma) ek analjezik gereksinimi, intraoperatif opioid gereksinimi kaydedildi.

Bulgular: Postoperatif toplam tramadol ve VAS skorları (dinlenme ve hareket) karşılaştıııldığında, iki grup arasında istatistiksel olarak anlamlı fark yoktu ( $p>0.05$ ).Yan etkiler (bulantı ve kusma), ek analjezik gereksinimi ve intraoperatif opioid gereksinimi açısından iki grup arasında istatistiksel olarak anlamlı fark yoktu $(p>0.05)$.

Sonuç: Çalışmamızın sonuçlarında hem lateral QLB hem de posterior QLB blok uygulamalarında postoperatif tramadol tüketim değerleri ve VAS skorları benzer olarak belirlendi.

Anahtar Kelimeler: Kolesistektomi, quadratus lumborum bloğu, postoperatif ağrı, laparoskopi, ultrason

Doi: $10.5578 /$ turkjsurg.4161 